\title{
Teachers' Use of Display vs. Referential Questions across Different Proficiency Levels
}

\author{
Mohammad Zohrabi \\ English Department, Faculty of Persian Literature and Foreign Languages \\ University of Tabriz, Tabriz, Iran \\ Tell: 00984113392192 E-mail: mohammadzohrabi@gmail.com \\ Massoud Yaghoubi-Notash \\ English Department, Faculty of Persian Literature and Foreign Languages \\ University of Tabriz, Tabriz, Iran \\ E-mail: masoud.yaghoubi@gmail.com \\ Sanaz Yousefzadeh Khiabani \\ English Department, Faculty of Persian Literature and Foreign Languages \\ University of Tabriz, Tabriz,Iran \\ E-mail: Yosefzadeh.s@gmail.com
}

Received: 10-11-2013

Accepted: 09-12-2013

Published: 01-03-2014

doi:10.7575/aiac.ijalel.v.3n.2p.96

URL: http://dx.doi.org/10.7575/aiac.ijalel.v.3n.2p.96

\begin{abstract}
With the growing interest in interaction in communicative language teaching, interactive features of classroom have gained more prominence. Questions as an important technique used by the teacher to promote classroom interaction have an important say in the matter. In this study the researchers investigated the frequency of use of two types of questions, that is, display and referential questions, at three levels of proficiency (elementary, intermediate and advanced). Furthermore, their interaction effect were compared within each level to see which question type led to the desirable effect, that is, more interaction at each level. To this end, one class from each level (elementary, intermediate, and advanced) which was taught by the same teacher was observed during a semester. The results showed that the teacher used more display questions at the elementary and intermediate levels contrary to the advanced level. Furthermore, the results elicited from the dependent t-test indicated that there was a significant difference in the effect of display versus referential questions at all of the three levels with referential ones leading to longer responses.
\end{abstract}

Key words: display/referential questions, interaction effect

\section{Introduction}

In this study it will be attempted to explore the effect of display and referential questions on three proficiency levels: elementary, intermediate, and advanced. There are some controversies on the use of display and referential questions. Some teachers embrace referential questions but others prefer display ones. Therefore, this study wants to find the merits and demerits of these two types of questions at three proficiency levels. We want to empirically observe which question type is helpful at what level.

\section{Review of the Related Literature}

The term interaction is a highly important term in communicative language teaching. It is considered as the core of teaching and learning process and through it acquisition can be facilitated (Long, 1983; Ellis, 1986; Brown, 2001). According to communicative language teaching theories, learners learn to use language communicatively through interaction in the target language and language classroom should be a place which provides the learners with the opportunities to learn through interaction.

The role of classroom interaction becomes even more conspicuous in foreign language settings, in that it is the only place that the learners have opportunities to use language communicatively. Therefore, there should be some attempts to increase the learner opportunities to interact and use all their language resources to convey meaning that they want to express. Unfortunately, in most EFL classes the students are silent and they are reluctant to participate in conversation. In this respect teacher plays a vital role in stimulating students to participate actively (Arifin, 2012). This stimulation can arise as a result of the implementation of appealing activities or through the use of thought provoking questions (Ozcan, 2010). Brock (1986), Gall (1970), Wu (1993) regard questioning as a worthwhile activity in teaching and consider it a popular method of involving students in a lesson and a tool for facilitating student participation.

Questions have an important role in the learning and teaching process. They are considered as contributing factor to students' language development (Arifin, 2012). Tan (2007) maintains that it is through questioning that teacher can 
divert students' attention to form or the content of the target language which in turn will shape both the process and outcome of individual development. According to Arifin (2012), the important roles of questioning in language classroom are to facilitate students to have comprehensible input, to trigger students to produce language production (output), and to create interaction in classroom.

Questions can serve different functions and teachers can ask questions for a variety of reasons. Chaudron (1988, p. 126) mentions that "teachers' questions constitute the primary means of engaging learners' attention, promoting verbal response, and evaluating learners' progress". There has been a great interest in the field towards the analysis of what purposes teachers' questions convey in the class. Different researchers provide different reasons for why teachers ask questions.

Richard and Lockhart (1996, p. 185) list the reasons for asking questions as follows:

- They stimulate and maintain students' interest.

- They encourage students to think and focus on the content of the lesson.

- They enable a teacher to clarify what a student has said.

- They enable a teacher to elicit particular structures or vocabulary items.

- They enable teachers to check students' understanding.

- They encourage student participation in a lesson.

Brown and Wragg (1996) suggest cognitive and cognate reasons for asking questions such as stimulating recall, deepening understanding, developing imagination, and encouraging problem solving. However, as it is the case in many language classrooms or in most teaching-learning settings, teachers ask questions particularly for one main reason, that is, to check understanding and knowledge (see Thornbury, 1996).

Studies of questioning have proposed various categories of questions and questions have been categorized according to their cognitive domain (Bloom, 1956); purpose (Richards \& Lockhart, 1996); form (Celce Murcia \& Larsen-Freeman, 1999; Biber et al., 1999), form, purpose and content (Thompson, 1997). While all of these types of questions have their place in the interactive classroom, among all the types of questions the distinction between display and referential question has attracted a lot of attention. Display questions are the ones for which the teacher already knows the answer, they simply test the learner's knowledge of previously taught studies, whereas, referential questions are genuinely information-seeking questions, aiming to acquire new information (Ellis, 1994).

A number of studies have compared the use of referential vs. display questions in foreign language classrooms. They have generally concluded that the situation in EFL setting is not very different from the British secondary classrooms that Sinclair and Coulthard (1970) studied. Also Long and Sato (1983) compared questions occurring in informal NSNNs conversation, and teacher-learner interaction in second language classroom. Lynch (1991, p. 202) summarized the findings as follows:

Referential (information seeking) questions, which predominate in NS-NNS conversation outside the classroom ( $76 \%$ of all questions asked) made up a mere $14 \%$ of questions asked by teachers. These results suggested that contrary to recommendation of many writers on second language teaching methodologies, communicative use of the target language makes up only minor part of typical classroom activities.

Brock (1986) studied the effects of referential questions on ESL classroom discourse. The research was conducted with four experienced ESL teachers and 24 non-native speakers. Two of the teachers were trained to integrate referential questions into their classroom instruction, whereas the other two were not. Brock found that the two teachers who had not been trained to use referential questions asked a total of 141 epistemic questions. Of the total, 24 were referential questions and 117 were display questions. In contrast, the teachers after having been trained to use referential questions asked 194 epistemic questions altogether. Of the total, 173 were referential questions and 21 were display. The study showed that those learners who were asked more referential questions produced significantly longer and more syntactically complex responses.

While Brock investigated the effects of the display versus referential questions on the length and complexity of the sentences produced by the learners, Shomossi (2004) examined the effect of questions in terms of interaction time.

Shomossi (2004) in a qualitative-quantitative study conducted as a classroom research, explored recurrent pattern of questioning behavior and their interactive effect. The results indicated that display questions were used by the teacher more frequently than referential questions. Also results showed that not all referential questions could create enough interaction.

A parallel study was carried out by David (2007) investigating the difference between the distribution of teachers' use of display and referential questions and also the effects of teachers' questioning behavior on ESL classroom interaction. He found that language teachers' use of display questions is much greater than their use of referential questions. Additionally, the researcher concluded that display questions create more opportunity for teacher-student exchanges in English language classrooms even though student involvement is minimal (12.4\%). The study also revealed that display questions encourage language learners, especially beginners, by stimulating interest and resulting in greater active participation in lessons. Similarly, Allwright and Bailey (1991) and Hickman (2004, as cited in David 2007) showed that display questions enable lower level language learners to have more opportunity to interact and participate in the classroom 
Contrary to Alright and Bailey (1991), David (2007) and Shomoossi (2004) who concluded that asking display questions is more beneficial and effective than referential questions in terms of facilitating student participation in lower level language classes, Ozcan (2010) indicates that lower level language learners participate more when asked a referential question.

\section{The Study}

\subsection{Participants}

The participants of this study were a teacher and a total of 46 students in three classes which were at elementary, intermediate and advanced levels respectively. These classes were mixed and there were 16 students, eight girl and eight boy students, at the elementary level, 15 students at the intermediate level out of which seven were boys and the others were girls. At the advanced level the participants consisted of seven boys and eight girls. The age of the students in these classes varied from 20 to 25 . The teacher was a 25 year old female holding an MA degree in TEFL with five years of teaching experience.

\subsection{Material and Procedure}

Having decided on the classes that the researchers were going to observe, they took part in those classes during one semester and used the IC recorder in order to audio record the classroom. During the observation the researchers used an observation checklist to check the occurrence of the predetermined feature of classroom interaction, that is, questions. To reduce the Hawthorne effect, the teacher was not informed of the focus of the study until the completion of the data collection. She was only given some general statements about the purpose of the study. In the case of students as the researchers took part in all the classes during the semester, the observer paradox was reduced, due to the researchers emerging in the context, allowing students to become accustomed to their presence. In transcription, the researchers transcribed all the questions asked by the teacher and the students' responses were transcribed. To identify questions, like Banbrook (1987), not only those beginning with interrogative but also any utterance ending with a rising intonation was considered as a question and transcribed. In transcribing the students' responses, the one that immediately followed the teacher's turn containing a question was considered as a response and once the teacher or another student took on a turn, the response was considered to have ended. In order to ensure that the inter-rater reliability was achieved, the recordings were given to another instructor to transcribe once more and the resulting interrater reliability was calculated. The resulting inter-rater reliability was 0.91 . After ensuring inter-rater reliability, the transcriptions were analyzed and the questions were categorized due to display and referential questions based on their definition given by Long and Sato (1983), Brock (1986), and Thornbury (1996). Then the number of display and referential questions used by the teacher in each session of the three desired levels were calculated. Furthermore, in order to compare their interactional effect at each level to see if there were significant differences in the mean length of responses articulated by the students for each type of question at each level, length of responses were calculated by means of the number of words. The results were interpreted by means of descriptive and inferential statistics.

\section{Data analysis and results}

In order to calculate the frequency of each type of question, the number of display and referential questions used by the teacher in each session of the three desired levels were calculated and the result were presented in the following table.

Table 1.Frequency means of each type of question at each level

\begin{tabular}{cll}
\hline Type & Display & Referential \\
\hline Elementary & 22.56 & 7.7 \\
\hline Intermediate & 19.72 & 8.89 \\
\hline Advanced & 7.61 & 11.67 \\
\hline
\end{tabular}

As the numbers indicate, the teacher's use of display and referential questions differ in all the three levels. Considering the mean frequencies, it's obvious that at the elementary level the teacher opted for more display use rather than referential one. At the intermediate level, the results once again reveal a preference for using display rather than referential questions, that is, 19.72 for the frequency mean of display as compared to 8.89 in referential. Although as can be seen in this level, the frequency use of display questions has decreased while the frequency of referential questions has increased when compared to the results of the elementary level, again the results are in favor of display questions. At the advanced level, unlike the previous levels, the results are in favor of referential questions, that is, 7.61 (for display) vs. 11.67 (for referential), thus clearly indicating a preference for referential questions at this level.

The main focus of the study had two sides to it, that is, investigating the interaction effect each question type causes within the three levels (that is, elementary, intermediate, and advanced) in Iranian EFL classrooms, in addition to the frequency of display/referential question use by the teacher at three proficiency levels. In order to compare the interaction effect within each level, the interaction effects (that is, the number of words per response) in all the three desired levels were recorded according to each session and their means were then calculated using SPSS. 
In order to determine whether the mean differences of interaction effects regarding display and referential questions at each level is significant or not, a dependent t-test was used. The elicited results from the dependent t-test are presented in the following table.

Table 2.Paired samples test results for interaction effect of display vs. referential questions at each level

\begin{tabular}{llll}
\hline Proficiency Level & t-value & df & sig. \\
\hline Elementary & -3.940 & 17 & .001 \\
\hline Intermediate & -3.361 & 16 & .004 \\
\hline Advanced & -6.309 & 17 & .000 \\
\hline
\end{tabular}

According to the information in Table 2, the significance level is less than the standard value which is 0.005 at all the three levels. Therefore, we can say that at all the three levels there was a significant difference in the interaction effect of display questions versus referential ones and at all the three levels referential questions led to higher interaction or in other words longer sentences compared with display ones.

\section{Discussion and Conclusion}

The results of our study indicated that the extent to which the teacher used display and referential questions at each proficiency level differed, that is, at the elementary and intermediate levels, the frequency of display questions used by the teacher overcame the referential types while the result was reversed for the advanced level. Overall, an interesting pattern was established that with the step up to higher proficiency levels, the frequency of display use decreased while the referential use increased. It seems that this preference in the use of questions results from the fact that the learners at elementary level haven't reached a certain proficiency threshold to be able to talk at length when confronted with referential questions, thus the teacher didn't want to pressure them into talking by asking them referential questions and by doing this she attempted to reduce the cognitive pressure on the learners. Furthermore, by asking more display questions, the teacher wanted to provide them with grammatical and vocabulary knowledge which she believed to be the prerequisites for speaking and in this way she prepared the students for more speaking in higher levels. Therefore, it seems that in the lower proficiency level (that is, elementary) the teachers are more concerned with accuracy and arming the learners with linguistic resources. With an increase in the learners' proficiency, the focus on accuracy is replaced with more attempts to increase the learners' fluency which reflects itself with asking more referential questions leading to more interaction.

The teachers' preference in the use of questions is in accordance with what Alright and Bailey (1991), David (2007) and Shomoossi (2004) in separate studies have suggested. They believe that since referential questions ask for learners' opinions and require information that is not provided within the text itself, they do not lead to the desired level of participation in lower level classes due to not having enough language to express their opinions. However, the results of the present study were in a complete disagreement with Alright and Bailey (1991), David (2007) and Shomoossi's (2004) line of thought. The paired t-test results showed that there was a meaningful difference in the interaction effect of display and referential question at all the three levels and that the interaction effect of the referential questions were higher than display ones at all the three levels.

The results of this study are in line with Ozcan (2010), who in a separate study indicated that referential questions increase student participation and talk time by means of longer responses during reading lessons in lower level classes. According to Ozcan (2010), the only obstacle that those students face when asked a question that requires their opinions and demands that they think critically, is the language barrier. Ozcan (2010) believes that in order to facilitate student participation, structures and chunks of languages should be provided to the students when necessary after the question is asked and that students should be given a certain amount of time to think over the question and discuss it in pairs. Therefore we can say that the lack of linguistic resources shouldn't be considered as an excuse for avoiding referential questions which our results indicated that lead to more interaction at the elementary level. The lack of linguistic resources could be avoided by providing the support learners need. In some situations this support may appear in the form of display questions. In other words, display questions may sometimes be used on the teachers' part in order to overcome the lack of linguistic resources on the learners' part. Overall, it seems that a mixture of both questions is needed thereby a balance should be maintained. Although teachers can divert the learners' attention to linguistic forms by asking display question, it is actually through speaking and using language to express ideas that learners can use their linguistic resources leading to opportunities to receive meaningful feedback. Furthermore, it should be noted that the saliency of structure or vocabulary may increase once the learners begin actually using them within a sentence.

By intending to increase the students' output, the results of this study may lead to improved speaking ability of the students. Furthermore, as the kind of activities and the tasks included in the text have decisive role in the types of questions teachers ask, the results of this study would also help syllabus designers to make the desired changes. Finally, the results of this study would be of help in teacher training programs. This can be achieved by means of emphasizing the importance of questions and the questioning skill and the role that they play in students' success.

Further investigations are still needed to shed more light on the issues contributing this area of study. For instance, for the sake of generalizability it would have been better if the study could be conducted with more than one teacher and 
more than one class in each proficiency level. Furthermore, it would be fruitful to collect the data for a longer period in a longitudinal fashion in order to increase its generalizability. On the other hand, the present study can be implemented according to each gender to see whether the results change according to each particular gender or not. This study could be conducted using an experimental design involving two treatment groups in order to determine which of the two treatment groups leads to a higher oral fluency. Bear in mind that this kind of study can be done within or among proficiency levels. Another research worth pursuing is the effects that display and referential questions may have on the complexity of the students' responses at different levels. This can also be carried out by means of an experimental design.

\section{References}

Arifin, T. (2012). Analyzing English as a foreign language (EFL) classroom interaction. APPLE3L JOURNAL, 1(1), 120.

Allwright, D. \& Bailey, K. M. (1991). Focus on the language classroom. Cambridge. CUP.

Banbrook, L. \& Skehan, P. (1989). Classrooms and display questions. In C. Brumfit \& R. Mitchell (Eds.), ELT Documents 133 (pp. 141-152). London: the British Council.

Biber, D., Johansson, S., Leech, G., Conrad, S., \& Finegan, E. (1999). Longman grammar of spoken and written English. Essex: Pearson Education Limited.

Bloom, B. (1956). Taxonomy of educational objectives: The classification of educational goals, Handbook I: Cognitive domain. New York: Longman Green.

Brock, C. A. (1986). The effects of referential questions on ESL classroom discourse. TESOL Quarterly, $20,77-59$.

Brown, G. \& Wragg, E. C. (1993). Questioning. London: Routledge.

Brown, H. D. (1994). Teaching by principles: An interactive approach to language pedagogy. Englewood Cliffs, New Jersey: Prentice Hall.

Celce-Murcia, M. \& Larsen-Freeman, D. (1999). The grammar book. Boston: Heinle \& Heinle.

Chaudron, C. (1988). Second language classrooms: Research on teaching and learning. Cambridge: CUP.

David, F. O. (2007). Teachers' questioning behavior and ESL classroom interaction pattern. Humanity \& Social Science Journal, 2(2), 127-131.

Ellis, R. (1985). Understanding second language acquisition. Oxford: OUP.

Ellis, R. (1994). The study of second language acquisition. Oxford: OUP.

Gall, M. D. (1970). The use of questions in teaching. Review of Educational Research, 40, 707-721.

Long, M. H. (1981). Questions in foreigner talk discourse. Language Learning, 31(1), 135-157.

Long, M, H. \& Sato, C. J. (1983). Classroom foreigner talk discourse: Forms and functions of teachers' questions. In H. W. Seliger \& M. H. Long (Eds.), Classroom oriented research in second language acquisition (pp. 3-34). Rowley, MA: Newbury House.

Lynch, T. (1991). Questioning roles in the classroom. ELT, 45(3), 201-210.

Ozcan, S. (2010). The effects of asking referential questions on the participation and oral production of lower level language learners in reading classes. Unpublished MA dissertation. Middle East Technical University.

Richards, J. C. \& Lockhart, C. (1996). Reflective teaching in second language classrooms. Cambridge: CUP.

Shomoossi, N. (2004). The effect of teacher's questioning behavior on EFL classroom interaction: A classroom research study. The Reading Matrix, 4, 96-104.

Sinclair, J. \& Coulthard, R. (1975). Toward an analysis of discourse. New York: OUP.

Tan, Z. (2007). Questioning in Chinese university EFL classroom. RELC Journal, 38(1), 87-102.

Thompson, G. (1997). Training teachers to ask questions. ELT Journal, 51(2), 99-104.

Thornbury, S. (1996). Teachers research teacher talk. ELT Journal, 50(4), 279-289.

Wu, K, Y, (1993). Classroom interaction and teacher questions revisited. RELC Journal, 24(22), 49-68. 